Article Type: Research Paper

\title{
Apresiasi Masayarakat Muslim Terhadap Perbankan Syariah di Kabupaten Nabire
}

\author{
Vivi Malasari ${ }^{1}$, Imamudin Yuliadi ${ }^{1}$, dan Hudiyanto $^{1}$
}

\begin{abstract}
Abstrak: Penelitian ini bertujuan untuk mengetahui dan menganalisis pengaruh faktor label syariah, sosialisasi, produk, riba, lingkungan, dan faktor referensi terhadap apresiasi masyarakat muslim terhadap perbankan syariah di Kabupaten Nabire. Subyek penelitian ini adalah masyarakat muslim di Distrik Nabire dan Distrik Nabire Barat. Penelitian ini menggunakan data primer dimana teknik pengumpulan data menggunakan metode angket kepada 397 responden. Teknik pengambilan sampel dengan menggunakan teknik Non-Probability Sampling dan teknik Slovin dengan cara Purposive Sampling. Metode yang digunakan adalah analisis regresi linier berganda dengan menggunakan softwere SPSS 21 . Hasil penelitian menunjukkan bahwa: Variabel label syariah, sosialisasi, produk, riba, lingkungan berpengaruh secara positif signifikan terhadap apresiasi masyarakat muslim. Sedangkan variabel referensi tidak berpengaruh terhadap apresiasi masyarakat muslim. Variabel Label Syariah, Sosialisasi, Produk, Riba dan Lingkungan dan Referensi secara simultan berpengaruh positif signifikan terhadap apresiasi masyarakat muslim terhadap perbankan syariah sebesar $55,8 \%$, sedangkan sisanya sebesar $44,2 \%$ dipengaruhi oleh faktor lain diluar penelitian ini.
\end{abstract}

Kata Kunci: Apresiasi Masyarakat Muslim; Perbankan Syariah; Regresi Linier Berganda.

Hudiyanto. (2020). Apresiasi

Masayarakat Muslim Terhadap

Perbankan Syariah di Kabupaten

Nabire. Journal of Economics

Research and Social Sciences, 4(1), 91-102.

\section{Pendahuluan}

Bank dalam suatu negara diibaratkan sebagai darahnya perekonomian negara tersebut. Peran perbankan pada dasarnya sangat mempengaruhi kegiatan ekonomi di suatu Negara. Perkembangan perbankan dapat menjadi ukuran dari tingkat kemajuan suatu Negara. Di mana ketika suatu negara mengalami kemajuan yang sangat besar maka besar pula pengaruh dari peranan perbankan dalam perekonomian negara tersebut. Hal ini menunjukkan bahwa perbankan sangat dibutuhkan bukan hanya oleh masyarakat namun juga dibutuhkan oleh pemerintah (Fadillah, 2016). Lembaga keuangan merupakan lembaga yang mempertemukan antara pihak yang mempunyai kelebihan dana (Surplus of funds) dengan pihak yang mengalami kekurangan dana (lack of funds) (Yuliadi, 2001). Lembaga keuangan syariah merupakan lembaga keuangan yang dalam operasionalnya menggunakan prinsip syariah dan terbebas dari riba. Berdirinya lembaga keuangan syariah bertujuan untuk menjalankan apa yang telah diperintahkan oleh Allah SWT dalam bidang ekonomi dan melayani masyarakat dengan menggunakan prinsip bagi hasil (Maghfiroh, 2018). Menurut Antonio (2001) Riba atau ziyadah merupakan tambahan yang sebelumnya telah ditentukan, berupa imbalan atas penangguhan 


\author{
Malasari, Yuliadi, \& Hudiyanto \\ Apresiasi Masayarakat Muslim Terhadap Perbankan Syariah di Kabupaten Nabire
}

waktu dalam pelunasan hutang maupun tidak. Menurut istilah, riba merupakan pengambilan tambahan dari utang pokok secara bathil.

Perkembangan perbankan syariah di Indonesia saat ini berdasarkan data dari statistik perbankan syariah dapat dilihat perkembangan bank syariah hingga pada bulan agustus 2018 jumlah kantor perbankan syariah sebanyak 2.637. Namun untuk provinsi Papua pertumbuhan perbankan syariah baik Bank Umum Syariah, Unit Usaha Syariah dan Bank Pembiayaan Rakyat Syariah dinilai sangat kurang bila di bandingkan dengan luas provinsi papua yaitu 216.553,07 $\mathrm{KM}^{2}$ dengan jumlah penduduk 3.265,202 jiwa. Menurut data data dari statistik perbankan syariah Sebaran Jaringan Kantor Bank Umum Syariah dan Unit Usaha Syariah di Provinsi Papua menunjukkan bahwa untuk Provinsi Papua hingga pada bulan agustus 2018 jumlah Kantor Pusat Operasional (KPO) sebanyak 2 unit kantor dan untuk Kantor Cabang Pembantu (KCP) sebanyak 5 unit kantor.

\title{
Tinjauan Pustaka
}

Dalam penelitian yang dilakukan oleh Romario (2016) dengan menggunakan metode purposive sampling. Peneliti memperoleh hasil di mana minat pelanggan untuk menjadi nasabah perbankan syariah disebabkan oleh beberapa faktor, faktor tersebut adalah faktor harga (ekonomis) dan produk. Serupa dengan penelitian yang dilakukan oleh Riko (2015) pada Bank Syariah (Studi Kasus pada PT. Bnk Muamalat Indonesia KCP Tanjungpandan, penulis menunjukkan bahwa dari tujuh faktor yaitu faktor lokasi, pelayanan, promosi, syariah, bagi hasil, fasilitas dan faktor produk hanya ada tiga faktor yang mempengaruhi minat nasabah non muslim menjadi nasabah di Bank Muamalat Indonesia KCP Tanjungpandan yaitu faktor bagi hasil sebesar $65.6 \%$, faktor produk sebesar $29.5 \%$ dan faktor syariah sebesar $24.9 \%$. Sedangkan empat faktor lainnya yaitu faktor lokasi, pelayanan, fasilitas dan promosi tidak berpengaruh terhadap minat nasabah non muslim menjadi nasabah di Bank Muamalat Indonesia KCP Tanjungpandan. Hasil penelitian lainnya oleh Novitasari (2015), dengan menggunakan metode kuantitatif survei, dan kualitatif deskriptif. Hasil penelitiannya menunjukkan bahwa variabel kesadaran merek (brand awareness), asosiasi merek (brand association), loyalitas merek (brand loyalty) berpengaruh positif, namun tidak signifikan terhadap proses keputusan penggunaan jasa perbankan syariah. Variabel lainnya seperti persepsi kualitas (perceived quality) tidak berpengaruh signifikan terhadap proses keputusan penggunaan jasa perbankan.

Hasil penelitian yang dilakukan oleh Bewiyanto (2014), dengan menggunakan teknik purposive sampling, peneliti menemukan bahwa kedua variabel bebas/independen memiliki pengaruh positif dan berpengaruh signifikan terhadap variabel terikat/dependen dengan nilai $R$-square sebesar 0,671. Di mana nilai koefisien variabel sosialisasi langsung (X1) yaitu sebesar 0,350 dan sosialisasi tidak langsung (X2) sebesar 0,375 . Dengan ditemukannya nilai koefisien sosialisasi tidak langsung yang lebih besar daripada koefisien sosialisasi langsung, menunjukkan bahwa sosialisasi secara tidak langsung seperti melalui periklanan dimedia cetak dan elektronik memiliki tingkat 


\author{
Malasari, Yuliadi, \& Hudiyanto \\ Apresiasi Masayarakat Muslim Terhadap Perbankan Syariah di Kabupaten Nabire
}

efektivitas yang lebih tinggi untuk meningkatkan minat masyarakat dalam menggunakan jasa Lembaga Keuangan Syariahdi Kecamatan Pleret Kabupaten Bantul.

\title{
Metode Penelitian
}

Jenis penelitian yang dilakukan merupakan jenis penelitian kuantitatif non eksperimental yaitu menggunakan metode kuantitatif survei. Peneliti melakukan pengumpulan data dengan cara menyebarkan kuisioner kepada responden yang telah ditentukan dengan menggunakan teknik pengambilan purposive sampling.

Populasi dalam penelitian ini adalah masyarakat muslim di Kabupaten Nabire khususnya di Distrik Nabire dan Distrik Nabire Barat yang berusia antara 17 hingga 60 tahun dengan jumlah keseluruhan penduduk pada tahun 2018 adalah sebanyak 43.846 jiwa.

Karena dalam pemilihan sampel mempunyai tujuan untuk memilih sampel yang mampu memberikan informasi mengenai apresiasi masyarakat muslim terhadap bank syariah di Kabupaten Nabire maka berdasarkan jumlah populasi penduduk muslim di distrik Nabire dan Nabire Barat yang memenuhi kriteria, maka diperoleh jumlah sampel yang akan digunakan sebagai responden oleh peneliti yang dihitung menggunakan rumus Slovin dengan tingkat signifikansi 95\% adalah 397 responden dengan yaitu 199 responden pada Distrik Nabire dan 198 responden pada Distrik Nabire Barat yang sesuai dengan kriteria sampel. Adapun kriteria sampel yang digunakan dalam penelitian ini yaitu, masyarakat muslim Kabupaten Nabire yang pernah melakukan transaksi di bank, telah bertransaksi selama 1 tahun atau lebih serta usia antara 17-60 tahun.

Penelitian ini dilakukan di Distrik Nabire dan Distrik Nabire Barat Kabupaten Nabire. Penelitian ini dimulai pada tanggal 20 November 2018 hingga tangga 20 Februari 2018. Menurut Sugiyono (2009) Skala likert digunakan dalam penelitian ini sebagai alat ukur variabel, dimana skala likert digunakan untuk mengukur sikap, pendapat, dan persepsi seseorang atau sekelompok orang mengenai fenomena sosial yang terjadi. Sehingga untuk mengetahui pengukuran jawaban responden pada penelitian ini yang mana menggunakan instrumen penelitian berupa kuesioner, dengan menggunakan metode skala likert (Likert's Summated Rating).

\section{Hasil dan Pembahasan}

Uji Validitas digunakan untuk mengukur valid atau tidaknya informasi yang diperoleh dari kuesioner yang disebar sehingga dapat dipastikan informasi yang diterima merupakan informasi yang akurat. Dengan mengkorelasikan angka yang diperoleh pada setiap pertanyaan dengan skor total dari masing-masing variabel. Metode korelasi yang digunakan adalah Pearson Correlation, ketika nilai Pearson Correlation $\geq 0,25$ maka pertanyaan dari variabel dikatakan valid (Basuki \& Prawoto, 2016). 
Malasari, Yuliadi, \& Hudiyanto

Apresiasi Masayarakat Muslim Terhadap Perbankan Syariah di Kabupaten Nabire

Tabel 1 Hasil Uji Validitas

\begin{tabular}{|c|c|c|c|c|}
\hline Variabel & Indikator & $\begin{array}{c}\text { Pearson } \\
\text { Correlatiom }\end{array}$ & Sig. & Keterangan \\
\hline \multirow[t]{5}{*}{ Label Syariah } & $\mathrm{X} 1.1$ & 0,843 & 0,000 & Valid \\
\hline & $X 1.2$ & 0,872 & 0,000 & Valid \\
\hline & $X 1.3$ & 0,861 & 0,000 & Valid \\
\hline & $X 1.4$ & 0,896 & 0,000 & Valid \\
\hline & $X 1.5$ & 0,872 & 0,000 & Valid \\
\hline \multirow[t]{5}{*}{ Sosialisasi } & $X 2.1$ & 0,834 & 0,000 & Valid \\
\hline & $X 2.2$ & 0,836 & 0,000 & Valid \\
\hline & $X 2.3$ & 0,888 & 0,000 & Valid \\
\hline & $X 2.4$ & 0,846 & 0,000 & Valid \\
\hline & $\times 2.5$ & 0,793 & 0,000 & Valid \\
\hline \multirow[t]{5}{*}{ Produk } & X3.1 & 0,806 & 0,000 & Valid \\
\hline & X3.2 & 0,859 & 0,000 & Valid \\
\hline & X3.3 & 0,821 & 0,000 & Valid \\
\hline & $X 3.4$ & 0,851 & 0,000 & Valid \\
\hline & X3.5 & 0,827 & 0,000 & Valid \\
\hline \multirow[t]{5}{*}{ Riba } & $X 4.1$ & 0,809 & 0,000 & Valid \\
\hline & $X 4.2$ & 0,823 & 0,000 & Valid \\
\hline & $X 4.3$ & 0,739 & 0,000 & Valid \\
\hline & $X 4.4$ & 0,811 & 0,000 & Valid \\
\hline & $X 4.5$ & 0,745 & 0,000 & Valid \\
\hline \multirow[t]{5}{*}{ Lingkungan } & $X 5.1$ & 0,766 & 0,000 & Valid \\
\hline & $\times 5.2$ & 0,646 & 0,000 & Valid \\
\hline & $X 5.3$ & 0,789 & 0,000 & Valid \\
\hline & $\times 5.4$ & 0,841 & 0,000 & Valid \\
\hline & $\times 5.5$ & 0,785 & 0,000 & Valid \\
\hline \multirow[t]{5}{*}{ Referensi } & X6.1 & 0,778 & 0,000 & Valid \\
\hline & $X 6.2$ & 0,879 & 0,000 & Valid \\
\hline & X6.3 & 0,852 & 0,000 & Valid \\
\hline & $X 6.4$ & 0,851 & 0,000 & Valid \\
\hline & $\times 6.5$ & 0,807 & 0,000 & Valid \\
\hline \multirow[t]{5}{*}{ Apresiasi } & Y.1 & 0,871 & 0,000 & Valid \\
\hline & Y.2 & 0,905 & 0,000 & Valid \\
\hline & Y.3 & 0,884 & 0,000 & Valid \\
\hline & Y.4 & 0,851 & 0,000 & Valid \\
\hline & Y.5 & 0,812 & 0,000 & Valid \\
\hline
\end{tabular}

Sumber : Data diolah

Berdasarkan hasil Uji Validitas yang ditunjukkan pada tabel $1.1 \mathrm{di}$ atas maka diperoleh hasil nilai korelasi Pearson Correlation pada seluruH pertanyaan dalam tujuh variabel penelitian adalah lebih dari 0,25 , sehingga seluruh pertanyaan dalam tujuh variabel pada kuesioner dapat dikatakan valid, sehingga dapat digunakan untuk analisis selanjutnya.

Uji Reliabilitas digunakan untuk memahami sejauh mana konsistensi suatu hasil pengukuran dari waktu ke waktu apabila pengukuran dilakukan dua kali atau lebih dengan menggunakan alat ukur yang sama dan indikasi yang sama pula. Uji Reabilitas 
digunkan dengan cara memasukkan angka korelasi kedalam rumus (Cronbach Alpha). Hasil Uji Reabilitas variabel dapat dilihat pada tabel di bawah ini.

Tabel 1.2 Hasil Uji Reabilitas

\begin{tabular}{lcc|}
\hline \multicolumn{1}{c}{ Variabel } & Cronbach Alpha & Keterangan \\
\hline Label Syariah (X1) & 0,918 & Reliabel \\
Sosialisasi (X2) & 0,895 & Reliabel \\
Produk (X3) & 0,889 & Reliabel \\
Riba (X4) & 0,841 & Reliabel \\
Lingkungan (X5) & 0,824 & Reliabel \\
Referensi (X6) & 0,890 & Reliabel \\
Apresiasi (Y) & 0,915 & Reliabel \\
\hline
\end{tabular}

Sumber : Data diolah

Berdasarkan hasil Uji Reliabilitas pada tujuh variabel label penelitian di atas menunjukkan bahwa nilai Cronbach's Alpha pada setiap variabel adalah lebih dari 0,07, artinya, instrumen penelitian yang digunakan dalam penelitian ini adalah data konsisten, sehingga dapat dikatakan bahwa variabel label syariah, sosialisasi, produk, riba, lingkungan, referensi dan variabel apresiasi memiliki reliabilitas tinggi (Basuki \& Prawoto, 2016).

Uji selanjutnya yang tidak kalah pentingnya, yakni Uji Asumsi Klasik. Pengujian ini dilakukan dengan beberapa tahap, tahap pertama yakni Uji Normalitas dengan menggunakan Kolmogorov-Smirnov test. Model dapat dikatakan berdistribusi normal ketika K-hitung < K tabel atau nilai signifikansi > nilai apha (Suliyanto, 2011).

Tabel 1.3 Hasil Uji Normalitas

\begin{tabular}{lc} 
& Unstandardized Residual \\
\hline Kolmogorov-Smirnov Z & 0,971 \\
Asymp. Sig & 0,302 \\
\hline
\end{tabular}

Sumber : Data diolah

Berdasarkan hasil Ujia Normalitas di atas, nilai signifikansinya adalah 0,302 atau lebih besar dari 0,05. Sehingga, dari hasil uji normalitas tersebut dapat dikatakan bahwa penelitian ini berdistribusi normal.

Tabel 1.4 Hasil Uji Heteroskedastisitas

\begin{tabular}{lcc}
\hline Variabel & Signifikansi & Keterangan \\
\hline Label Syariah (X1) & 0,081 & Bebas Heteroskedastisitas \\
Sosialisasi (X2) & 0,282 & \\
Produk (X3) & 0,094 & \\
Riba (X4) & 0,312 & \\
Lingkungan (X5) & 0,086 & \\
Referensi (X6) & 0,696 & \\
\hline
\end{tabular}

Sumber : Data diolah

Berdasarkan hasil Uji Heteroskedastisitas, nilai signifikansi variabel label syariah adalah sebesar 0,081, nilai signifikansi variabel sosialisasi sebesar 0,282, nilai signifikansi variabel produk sebesar 0,094 , nilai signifikansi variabel riba sebesar 0,312 , nilai 
signifikansi variabel lingkungan sebesar 0,086 dan nilai signifikansi variabel referensi adalah sebesar 0,696. Berdasarkan nilai signifikansi hasil uji heteroskedastisitas tersebut, dapat dikatakan bahwa model tidak mengandung heteroskedastisitas karena semua nilai signifikansi dari variabel-variabel independen di atas lebih besar dari pada alpha $(0,05)$.

Tabel 1.5 Hasil Uji Multikolinearitas

\begin{tabular}{lccc}
\hline \multicolumn{1}{c}{ Variabel } & Tolerance & VIF & Keteranagan \\
\hline Label Syariah (X1) & 0,748 & 1,337 & Bebas Multikolinearitas \\
Sosialisasi (X2) & 0,453 & 2,208 & \\
Produk (X3) & 0,437 & 2,286 & \\
Riba (X4) & 0,414 & 2,415 & \\
Lingkungan (X5) & 0,720 & 1,388 & \\
Referensi (X6) & 0,743 & 1,345 & \\
\hline
\end{tabular}

Sumber : Data diolah

Berdasarkan hasil Uji Multikolinearitas di atas dapat dilihat bahwa variabel label syariah, sosialisasi, produk, riba, lingkungan dan referensi memiliki nilai Tolerance di atas 0,01 dan nilai VIF kurang dari 10, sehingga dapat dikatakan bahwa variabel variabel label syariah, sosialisasi, produk, riba, lingkungan dan referensi bebas dari penyakit multikolinearitas.

Tabel 1.6 Hasil Uji Hipotesis Secara Simultan

\begin{tabular}{lccccc}
\hline \multicolumn{1}{c}{ Model } & Sum of Aquares & df & Mean Square & F & Sig. \\
\hline Regression & 2425.201 & 6 & 404.200 & 84,394 & 0,000 \\
Residual & 1867.892 & 390 & 4.789 & & \\
Total & 4293.093 & 396 & & & \\
\hline
\end{tabular}

Sumber : Data diolah

Berdasarkan hasil uji hipotesis secara simultan, diperoleh hasil nilai signifikansi dari variabel bebas adalah 0,000 atau $<0,05$ dan nilai $F_{\text {hitung }}>F_{\text {tabel }}$ sebesar $(84,394>2,122)$, sehingga dapat disimpulkan bahwa variabel independen label syariah, sosialisasi, produk, riba, lingkungan dan referensi secara simultan berpengaruh signifikan terhadap variabel dependen apresiasi masyarakat muslim.

Untuk menguji hipotesis pada penelitian ini, perlu untuk melakukan pengujian lebih lanjut, yakni Uji T. Penilaian dapat di lakukan dengan melihat nilai t pada tabel coefficients, dengan menggunakan rumusan hipotesis yaitu ketika nilai signifikansi lebih kecil dari 0,05 dan nilai $t_{\text {hitung }}>t_{\text {tabel, }}$ maka HO ditolak dan H1 diterima (Basuki \& Prawoto, 2016)

Tabel 1.7 Hasil Uji Hipotesis Secara Parsial

\begin{tabular}{lccccc}
\hline \multicolumn{1}{c}{ Model } & \multicolumn{2}{c}{$\begin{array}{c}\text { Unstandardized } \\
\text { Coefficients }\end{array}$} & $\begin{array}{c}\text { Standardized } \\
\text { Coefficients }\end{array}$ & $\mathrm{t}$ & Sig. \\
& $\mathrm{B}$ & Std. Error & Beta & & \\
\hline (Constant) & 1.080 & 0.916 & & 1.180 & 0.239 \\
Label Syariah & 0.299 & 0.036 & 0.322 & 8.341 & 0.000 \\
Sosialisasi & 0.134 & 0.055 & 0.122 & 2.454 & 0.015 \\
Produk & 0.329 & 0.052 & 0.322 & 6.367 & 0.000 \\
\hline
\end{tabular}


Malasari, Yuliadi, \& Hudiyanto

Apresiasi Masayarakat Muslim Terhadap Perbankan Syariah di Kabupaten Nabire

\begin{tabular}{lccccc}
\hline Riba & 0.123 & 0.057 & 0.111 & 2.146 & 0.032 \\
Lingkungan & 0.105 & 0.044 & 0.094 & 2.389 & 0.017 \\
Referensi & -0.016 & 0.043 & -0.014 & -0.371 & 0.711 \\
\hline
\end{tabular}

Sumber : Hasil olah data primer menggunakan SPSS 21

Berdasarkan hasil uji-t, nilai signifikansi variabel label syariah adalah sebesar 0,000 dan nilai Unstandardized Coefficients B adalah 0,299. Dari hasil tersebut dapat disimpulkan bahwa variabel label syariah berpengaruh secara signifikan terhadap apresiasi masyarakat muslim terhadap perbankan syariah, dan variabel label syariah mempengaruhi apresiasi masyarakat muslim sebesar 0,299, sehingga HO ditolak. Artinya, jika label syariah naik sebesar 1.000 satuan, maka apresiasi masyarakat muslim terhadap perbankan syariah akan naik sebesar 299 satuan. Jadi, dapat disimpulkan bahwa semakin banyak perbankan yang menggunakan label syariah akan semakin meningkatkan apresiasi masyarakat muslim terhadap perbankan Syariah.

Sesuai dengan penelitian Sukhmono (2011), Label syariah berkaitan dengan kepercayaan konsumen terhadap suatu produk atau layanan, yang diyakini tidak saja dapat memenuhi kebutuhan mereka, tetapi dengan memberikan kepuasan yang lebih baik dan terjamin. Sehingga dengan adanya label syariah pada perbankan dapat menjamin akan kebutuhan masyarakat dan juga mengurangi atau bahkan dapat menghilangkan keraguan masyarakat mengenai perbankan yang mengandung unsur riba.

Menurut wawancara yang dilakukan oleh peneliti kepada responden yang bernama Ibu Sudiyati pada tanggal 4 Januari 2019, beliau mengatakan bahwa ketika ada perbankan yang menggunakan label syariah berarti telah menjamin bahwa bank tersebut bebas dari dosa riba, beliau juga mengatakan bahwa sama halnya dengan makanan yang berlabel halal, berarti tidak ada keraguan untuk mengonsumsi barang tersebut. Hal ini juga diperkuat oleh penelitian terdahulu yang di lakukan oleh Novitasari (2015) di mana variabel kesadaran merek, asosiasi merek, dan loyalitas merek berpengaruh positif terhadap keputusan menggunakan jasa perbankan syariah. Penelitian lain yang di lakukan oleh Agusman (2018) memperoleh hasil bahwa label syariah secara parsial berpengaruh positif signifikan terhadap minat menabung masyarakat.

Berdasarkan hasil uji-t, nilai signifikansi variabel sosialisasi adalah sebesar 0,015 dan nilai Unstandardized Coefficients B adalah 0,134. Dari hasil tersebut dapat disimpulkan bahwa variabel sosialisasi berpengaruh secara signifikan terhadap apresiasi masyarakat muslim terhadap perbankan syariah, dan variabel sosialisasi mempengaruhi apresiasi masyarakat muslim sebesar 0,134 , sehingga HO ditolak. Artinya, jika sosialisasi naik sebesar 1.000 satuan, maka apresiasi masyarakat muslim terhadap perbankan syariah akan naik sebesar 134 satuan. Sehingga, dapat disimpulkan bahwa semakin sering perbankan syariah melakukan sosialisasi kepada masyarakat akan semakin meningkatkan apresiasi masyarakat muslim terhadap perbankan syariah.

Menurut Lindrianti (2017), Sosialisasi diartikan sebagai sebuah proses seseorang mempelajari kebiasaan-kebiasaan yang meliputi cara-cara hidup, nilai-nilai, dan normanorma sosial yang terdapat dalam masyarakat agar dapat diterima oleh masyarakatnya. Berdasarkan wawancara yang dilakukan oleh peneliti kepada bapak Riyadi pada tanggal 


\author{
Malasari, Yuliadi, \& Hudiyanto \\ Apresiasi Masayarakat Muslim Terhadap Perbankan Syariah di Kabupaten Nabire
}

4 Januari 2019, beliau mengatakan bahwa beliau ingin sekali membebaskan diri dari hutang bank dan koperasi yang mengandung riba, beliau mendengar mengenai perbankan syariah yang bebas dari unsur riba, namun beliau belum mengetahui secara jelas apa itu perbankan syariah dan produk-produk yang ditawarkan, maka beliau mengharapkan adanya sosialisasi kepada masyarakat agar lebih memahami perbankan syariah dan juga mengharapkan adanya perbankan syariah di Kabupaten Nabire.

Penelitian ini sejalan dengan penelitian yang dilakukan oleh Bewiyanto (2014) di mana hasil penelitiannya menunjukkan bahwa sosialisasi langsung dan sosialisasi tidak langsung memiliki pengaruh secara positif signifikan terhadap minat masyarakat dalam menggunakan jasa lembaga keuangan syariah (Studi kasus Kecamatan Pleret Kabupaten Bantul Yogyakarta). Penelitian lain yang juga sejalan dengan penelitian ini dilakukan oleh Ananda, Kumadji dan Husain (2015), dengan penelitian menunjukkan sosialisasi perpajakan memiliki pengaruh signifikan terhadap kepatuhan wajib pajak.

Berdasarkan hasil uji-t, nilai signifikansi variabel produk adalah sebesar 0,000 dan nilai Unstandardized Coefficients B adalah 0,329. Dari hasil tersebut dapat disimpulkan bahwa variabel produk berpengaruh secara signifikan terhadap apresiasi masyarakat muslim terhadap perbankan syariah, dan variabel produk mempengaruhi apresiasi masyarakat muslim sebesar 0,329 , sehingga $\mathrm{HO}$ ditolak. Artinya, jika produk naik sebesar 1.000 satuan, maka apresiasi masyarakat muslim terhadap perbankan syariah akan naik sebesar 329 satuan. Oleh karena itu, dapat disimpulkan bahwa produk perbankan Syariah apabila semakin menarik dan semakin memenuhi kebutuhan para nasabah perbankan syariah akan semakin meningkatkan apresiasi masyarakat muslim terhadap perbankan syariah.

Sejalan dengan penelitian ini, dalam penelitian yang di lakukan oleh Romario (2016) bahwasannya minat pelanggan untuk menjadi nasabah perbankan Syariah disebabkan oleh beberapa faktor, faktor tersebut adalah faktor harga (ekonomis) dan produk. Penelitian lain yang juga sejalan di lakukan oleh Riko (2015) di mana hasil penelitian menunjukkan faktor produk mempengaruhi minat nasabah non-muslim menjadi nasabah di Bank Muamalat Indonesia KCP Tanjungpandan sebesar 29.5\%.

Berdasarkan hasil uji-t, nilai signifikansi variabel riba adalah sebesar 0,032 dan nilai Unstandardized Coefficients B adalah 0,123. Dari hasil tersebut dapat disimpulkan bahwa variabel riba berpengaruh secara signifikan terhadap apresiasi masyarakat muslim terhadap perbankan syariah, dan variabel riba mempengaruhi apresiasi masyarakat muslim sebesar 0,123 , sehingga HO ditolak. Artinya, jika riba naik sebesar 1.000 satuan, maka apresiasi masyarakat muslim terhadap perbankan syariah akan naik sebesar 123 satuan. Jadi, dapat disimpulkan bahwa semakin tinggi pengetahuan masyarakat mengenai riba dan bank syariah terbebas dari riba maka akan semakin meningkatkan apresiasi masyarakat muslim terhadap perbankan syariah.

Dalam wawancara yang peneliti lakukan kepada Bapak Baharuddin pada tanggal 23 Januari 2019, beliau mengatakan masyarakat muslim masih banyak yang tidak mengetahui bahaya riba dalam perbankan konvensional, hal itu di tambah dengan 


\section{Malasari, Yuliadi, \& Hudiyanto \\ Apresiasi Masayarakat Muslim Terhadap Perbankan Syariah di Kabupaten Nabire}

belum adanya perbankan syariah di Kabupaten Nabire sehingga masyarakat muslim tidak memiliki pilihan lain. Sehingga beliau sangat mengharapkan adanya perbankan syariah di Kabupaten Nabire, sehingga masyarakat muslim memiliki pilihan dan dapat terhindar dari dosa riba.

Hal ini sejalan dengan penelitian yang dilakukan oleh Imran dan Hendrawan (2017) di mana variabel persepsi tentang bunga bank secara positif signifikan berpengaruh terhadap minat menggunakan produk bank syariah. Namun penelitian ini tidak sejalan dengan penelitian lain yang dilakukan oleh Widiastini (2014) di mana hasil penelitian tersebut menunjukkan bahwa riba tidak berpengaruh secara signifikan terhadap minat menabung masyarakat pada Bank Syariah dengan nilai koefisien negatif yaitu $-0,064$ dan probabilitas sebesar $0,616>\alpha 5 \%$.

Berdasarkan hasil uji-t, nilai signifikansi variabel lingkungan adalah sebesar 0,017 dan nilai Unstandardized Coefficients B adalah 0,105. Dari hasil tersebut dapat disimpulkan bahwa variabel lingkungan berpengaruh secara signifikan terhadap apresiasi masyarakat muslim terhadap perbankan syariah, dan variabel lingkungan mempengaruhi apresiasi masyarakat muslim sebesar 0,105, sehingga HO ditolak. Artinya, jika lingkungan naik sebesar 1.000 satuan, maka apresiasi masyarakat muslim terhadap perbankan syariah akan naik sebesar 105 satuan. Maka, dapat disimpulkan bahwa semakin baik lingkungan yang positif terhadap perbankan syariah maka akan semakin meningkatkan apresiasi masyarakat muslim terhadap perbankan syariah.

Menurut Peter dan Olson (2016) Lingkungan sosial mencakup semua interaksi sosial di antara dua orang atau lebih. Konsumen berinteraksi dengan orang lain secara langsung atau secara model. Lingkungan sosial makro merujuk kepada interaksi sosial tidak langsung dan interaksi model di antara kelompok-kelompok orang yang sangat besar. Lingkungan sosial mikro meliputi interaksi sosial tatap muka di antara kelompokkelompok orang yang lebih kecil seperti keluarga dan Kelompok Acyan. Interaksi sosial langsung bisa berpengaruh kuat terhadap pengetahuan dan perasaan konsumen akan produk, toko, iklan, dan perilaku konsumsinya.

Dalam wawancara yang dilakukan oleh peneliti kepada responden yang bernama ibu Siti pada tanggal 19 Januari 2019, beliau mengatakan bahwa lingkungan tempat beliau tinggal merupakan lingkungan yang islami, dalam pengajian yang beliau ikuti juga sering membahas mengenai riba dalam bunga perbankan, dikarenakan beliau tidak memiliki pilihan, beliau hanya menggunakan perbankan untuk menerima gaji saja. Sejalan dengan penelitian yang dilakukan oleh Yusuf (2016) di mana hasil penelitian menunjukkan variabel lingkungan memiliki pengaruh signifikan terhadap minat etnis Tionghoa dalam memilih perbankan syariah.

Berdasarkan hasil uji-t, nilai signifikansi variabel referensi adalah sebesar 0,711 dan nilai Unstandardized Coefficients B adalah -0,016. Dari hasil tersebut dapat disimpulkan bahwa variabel referensi tidak berpengaruh secara signifikan terhadap apresiasi masyarakat muslim terhadap perbankan syariah, sehingga $\mathrm{HO}$ diterima. 


\section{Malasari, Yuliadi, \& Hudiyanto \\ Apresiasi Masayarakat Muslim Terhadap Perbankan Syariah di Kabupaten Nabire}

Dalam wawancara yang dilakukan oleh peneliti kepada responden bernama ibu Asiah pada tanggal 2 Februari 2019, beliau mengatakan bahwa beliau belum pernah mendapatkan informasi mengenai perbankan syariah baik melalui media, media elektronik maupun sosial media, sehingga beliau kurang memahami mengenai perbankan syariah. Dari hasil penelitian ini berbeda dengan penelitian yang di lakukan oleh Magfiroh (2018), di mana dalam penelitian tersebut memperoleh hasil bahwa sebesar 6,747 referensi mempengaruhi Minat Nasabah dalam Menabung di BMT An-Nur Rewin Sidoarjo.

Berdasarkan hasil uji-t di atas, dapat disimpulkan bahwa variabel label syariah, sosialisasi, produk, riba, dan lingkungan berpengaruh signifikan terhadap apresiasi masyarakat muslim terhadap perbankan syariah di Kabupaten Nabie, namun variabel referensi tidak berpengaruh signifikan terhadap apresiasi masyarkat muslim terhadap perbankan syariah di Kabupaten Nabire.

Tabel 1.8 Hasil Uji $R^{2}$ (Koefisien Determinasi)

\begin{tabular}{cccc}
\hline$R$ & $R$-Squared & Adjusted R-Squared & $\begin{array}{c}\text { Std. Error of the } \\
\text { Estimate }\end{array}$ \\
\hline $\mathbf{0 , 7 5 2}$ & 0,565 & 0,558 & 2.188 \\
\hline
\end{tabular}

Sumber : Data diolah

Berdasarkan hasil uji $R$-squared atau koefisien determinasi di atas, diketahui bahwa nilai Adjusted $R$ Squared adalah 0,558, yang artinya variabel independen (label syariah, sosialisasi, produk, riba, lingkungan, referensi) dapat mempengaruhi variabel dependen (apresiasi masyarakat muslim) sebesar 55,8 persen, sedangkan 44,2 persen dipengaruhi oleh variabel lain di luar model.

\section{Kesimpulan}

Berdasarkan hasil analisis data, pengujian hipotesis dan pembahasan dengan menggunakan variabel dependen apresiasi masyarakat muslim dan variabel independen yaitu label syariah, sosialisasi, produk, riba, lingkungan dan apresiasi, maka dapat disimpulkan bahwa variabel label syariah, sosialisasi, produk, riba dan lingkungan berpengaruh secara positif signifikan terhadap apresiasi masyarakat muslim. Berbeda dengan variabel yang lainnya, variabel referensi tidak berpengaruh secara signifikan terhadap apresiasi masyarakat muslim.

Berdasarkan hasil penelitian dan kesimpulan di atas, maka penulis memberikan beberapa saran atau masukan yang sekiranya dapat bermanfaat bagi pihak terkait. Informasi terkait perbankan syariah perlu ditingkatkan lagi. Berdasarkan hasil penelitian bahwasannya variabel referensi tidak berpengaruh secara positif signifikan, sehingga perbankan syariah diharapkan dapat lebih meningkatkan penyebaran informasi mengenai perbankan syariah baik melalui media elektronik, media cetak, maupun media sosial sehingga akan semakin meningkatkan apresiasi masyarakat muslim terhadap perbankan syariah. Hal lainnya yakni, Bank syariah di harapkan dapat memperluas 
jaringannya dengan menambah kantor di Provinsi Papua, Khususnya di Kabupaten Nabire.

\section{Daftar Pustaka}

Agusman, R. (2018). Pengaruh Label Syariah Terhadap Minat Menabung Masyarakat Pada Bank Syariah Mandiri Cabang Medan Sunggal. Skripsi-Universitas Sumatera Utara.

Ananda, P. R. D., Kumadji, S., \& Husaini, A. (2015). Pengaruh Sosialisasi Perpajakan, Tarif Pajak, dan Pemahaman Perpajakan Terhadap Kepatuhan Wajib Pajak: Studi Pada UMKM yang Terdaftar Sebagai Wajib Pajak di Kantor Pelayanan Pajak Pratama Batu. Jurnal Perpajakan, 6(2), 1-9. Diakses dari http://perpajakan.studentjournal.ub.ac.id/index.php/perpajakan/article/view/201 Antonio, M. S. (2001). Bank Syariah: dari Teori ke Praktik. Jakarta: Gema Insani.

Basuki, A. T., \& Prawoto, N. (2016). Analisis Regresi dalam Penelitian Ekonomi dan Bisnis. Depok: Raja Grafindo Persada.

Bewiyanto, A. S. (2014). Pengaruh Sosialisasi Terhadap Minat Masyarakat Dalam Menggunakan Jasa Lembaga Keuangan Syariah; Studi Kasus Kecamatan Pleret Kabupaten Bantul Yogyakarta. Skripsi-Universitas Muhammadiyah Yogyakarta. Fadillah, M. A. (2016). Pengaruh Pelayanan, Promosi, dan Profit-Loss Sharing Terhadap Keputusan Masyarakat Menjadi Nasabah di Bank Syariah Mandiri. Skripsi-Universitas Muhammadiyah Yogyakarta.

Imran, I., \& Hendrawan, B. (2018). Pengaruh Persepsi Masyarakat Batam Tentang Bank Syariah Terhadap Minat Menggunakan Produk Bank Syariah. Journal Of Applied Business Administration, 1(2), 209-218. https://doi.org/10.30871/jaba.v1i2.621

Lindrianti, S. (2017). Pengaruh Sosialisasi dan Tingkat Pemahaman Masyarakat Terhadap Minat Pembuatan Akta Kematian di Desa Purworejo. Skripsi. Fakultas Keguruan dan Ilmu Pendidikan. Universitas Lampung.

Maghfiroh, N. L. (2018). Analisis Faktor - Faktor Yang Mempengaruhi Minat Masyarakat Untuk Menabung; Studi Kasus pada Nasabah BMT An-Nur Rewwin Sidoarjo. Skripsi-Universitas Islam Negeri Sunan Ampel.

Novitasari, H. (2015). Pengaruh Ekuitas Merek (Brand Equity) Terhadap Proses Keputusan Penggunaan Jasa Perbankan Syariah; Studi Kasus PT. Bank Syariah Mandiri Kantor Cabang Pembantu Bantul Yogyakarta. Skripsi-Universitas Muhammadiyah Yogyakarta.

Peter, J. P., \& Olson, J. C. (2014). Perilaku konsumen dan strategi pemasaran. Edisi Sembilan. Jakarta: Salemba Empat.

Riko, P. (2015). Analisis Faktor-faktor yang Mempengaruhi Minat Nasabah Non Muslim Menjadi Nasabah di Bank Syariah: Studi Kasus pada PT. Bank Muamalat Indonesia KCP Tanjungpandan. Skripsi-Universitas Muhammadiyah Yogyakarta.

Romario. (2016). Faktor-Faktor Yang Mempengaruhi Customer Menjadi Nasabah Bank Syariah. Skripsi-Universitas Muhammadiyah Yogyakarta.

Sugiyono. (2009). Metode Penelitian Pendidikan Pendekatan Kuantitatif, Kualitatif, dan ReDD. Bandung : Alfabeta.

Sukhmono, B. R. (2011). Pengaruh Label Syariah Pada Lembaga Perbankan Terhadap Jumlah Nasabah BNI Syariah Cabang Jakarta Selatan. Skripsi-Universitas Islam Negeri Syarif Hidayatullah.

Suliyanto. (2011). Ekonometrika Terapan-Teori dan Aplikasi dengan SPSS. Yogyakarta: CV Andi Offset. 
Widiastini. (2014). Analisis Faktor-Faktor Yang Mempengaruhi Minat Masyarakat Untuk Menabung Pada Bank Syariah; Studi Kasus Bank Syariah Di Daerah Istimewa Yogyakarta. Skripsi-Universitas Muhammadiyah Yogyakarta.

Yuliadi, I. (2001). Ekonomi Islam. Yogyakarta : Lembaga Pengkajian dan Pengalaman Islam (LPPI).

Yusuf, M. Y., \& Jalilah. (2016). Persepsi Etnis Tionghoa Dalam Meningkatkan Minat Terhadap Perbankan Syariah di Banda Aceh. Journal-Ekonomi Syariah. 4(2), 195-210. Diakses dari file:///C:/Users/acer\%202/Downloads/1944-8634-1-PB.pdf 